\title{
The labour market integration of migrants and refugees: career guidance and the newly arrived
}

\author{
Ronald G. Sultana ${ }^{1}$ (1)
}

Received: 22 June 2021 / Accepted: 28 January 2022 / Published online: 12 February 2022

(C) The Author(s), under exclusive licence to Springer Nature B.V. 2022

\begin{abstract}
This scoping paper sets out to consider various aspects of the phenomenon of people on the move, and to examine some of the ways in which career guidance has responded to the challenge of integrating the newly arrived. The paper is informed by a recognition of the dignity of individuals above any classificatory system that places persons in a hierarchy, with some having access to rights that others are denied. This stance requires career practitioners to confront the prevalent vocabulary, discourses and attitudes circulating in the mainstream in order to become aware of - and to overcome-personal prejudice, thus opening up possibilities for more socially just forms of service. A synthesis of relevant literature concerning the integration of migrants and refugees in the labour market is provided in order to signpost emancipatory forms of career guidance, ones that move beyond an emphasis on individual resilience to take seriously the impact of exclusionary social practices and structures. The paper concludes by highlighting a number of initiatives that suggest that career guidance is rising to the challenge of catering for a diverse group of newly arrived by mobilising theoretical frameworks that are fit for purpose, by developing bespoke training programmes for practitioners, and by sharing the lessons learnt from the field.
\end{abstract}

Keywords Migrants · Refugees · Emancipatory career guidance

\section{Résumé}

Cet article considère les personnes en mouvement, et comment l'orientation professionnelle a soutenu l'intégration des nouveaux et nouvelles arrivant-e-s. L'article s'appuie sur la reconnaissance de la dignité de tous les individus, une position qui exige des praticien-enne-s de faire face aux préjugés découlant du vocabulaire, des discours et des attitudes qui circulent dans le grand public, ouvrant ainsi la voie à des formes de service plus justes socialement. L'article conclut en soulignant quelques

Ronald G. Sultana

ronald.sultana@um.edu.mt

1 Euro-Mediterranean Centre for Educational Research, University of Malta, Msida MSD2080, Malta 
initiatives récentes à ce propos. Celles-ci incluent la mobilisation de cadres théoriques adaptés, le développement de programmes de formation sur mesure pour les praticien-enne-s, ainsi que le partage des leçons apprises sur le terrain.

\section{Zusammenfassung}

Die Arbeitsmarktintegration von Migranten und Flüchtlingen: Berufsorientierung und Neuankömmlinge

Dieses Scoping-Papier befasst sich mit Menschen auf der Flucht und wie Berufsberatung die Integration von Neuankömmlingen unterstützt hat. Das Papier basiert auf der Anerkennung der Würde aller Menschen, einer Haltung, die von Praktikern verlangt, sich Vorurteilen zu stellen, die sich aus dem im Mainstream zirkulierenden Vokabular, Diskursen und Einstellungen ergeben, und so Möglichkeiten für sozial gerechtere Formen des Dienstes zu eröffnen. Der Beitrag schließt mit der Hervorhebung des emanzipatorischen Potenzials der jüngsten Initiativen. Dazu gehören die Mobilisierung passender theoretischer Rahmen, die Entwicklung maßgeschneiderter Schulungsprogramme für Praktiker und der Austausch von Erfahrungen aus der Praxis.

\section{Resumen}

\section{La inserción laboral de inmigrantes y refugiados: Orientación laboral y recién llegados}

Este documento de alcance considera a las personas en movimiento y cómo la orientación profesional ha apoyado la integración de los recién llegados. El documento está informado por un reconocimiento de la dignidad de todos los individuos, una postura que requiere que los profesionales enfrenten los prejuicios que surgen del vocabulario, los discursos y las actitudes que circulan en la corriente principal, abriendo así posibilidades para formas de servicio socialmente más justas. El documento concluye destacando el potencial emancipador de las iniciativas recientes. Estos incluyen la movilización de marcos teóricos apropiados, el desarrollo de programas de capacitación personalizados para profesionales y el intercambio de lecciones aprendidas en el campo.

Migration is an expression of the human aspiration for dignity, safety and a better future. It is part of the social fabric, part of our very make-up as a human family. Ban Ki-moon, 8th Secretary General of the United Nations (UN, 2013).

\section{Introduction}

This scoping paper sets out to provide an overview of some of the more important aspects of the relationship between career guidance and the integration of the newly arrived in the labour market. It starts off by problematising and challenging the manner in which migrants and refugees are often portrayed, highlighting some of the most salient facts about the movement of peoples worldwide. This serves to challenge the mainstream discourse which creates a panic around a purported 'refugee 
crisis,' and which speaks of those seeking asylum and a better life as a burden and a drain on the resources of the state. Careful and critical consideration of the vocabulary that is often used opens up important conversations about the way in which historically contingent 'discursive ecologies' shape subjectivities and behaviour, shortcircuiting the development of emancipatory guidance services informed by social justice.

The paper then trawls some of the most relevant literature on the labour market integration of the newly arrived, noting that the complex challenges that individuals, groups, and systems have to face require integrated solutions, of which career guidance can be a part. While highlighting the diversity among the newly arrived, the paper also identifies a core of services and approaches that have proven valuable in catering for a range of needs, and which serve to enhance self-identity, cultural competence, and awareness of one's duties and rights. Career guidance therefore has a role to play in the integration of refugees and migrants in the labour market, particularly if it avoids a focus on individualistic approaches that emphasise resilience and voluntaristic life design at the expense of advocacy and a comprehensive and informed critique of exclusionary social structures.

The paper concludes by identifying policies, practices and initiatives that illustrate the ways in which the career guidance profession seeks to meet the challenge of catering for a diverse group of migrants and refugees. It is doing so by mobilising theoretical frameworks that are fit for purpose, by developing and enhancing training programmes for practitioners, and by drawing on the lessons learnt by those working in the field. Examples of each are provided in turn, in the hope that they will serve as an inspiration for the articulation of more effective and socially just practice.

\section{Facing the facts}

A history of humanity is indeed a history of mobility, of migration from one place to another: we are all nomads or descendants of nomads at the end of the day, and we are all out of Africa (Stewart \& Stringer, 2012). And yet, if we go by declarations of (some) state leaders and by representations of mainstream media, the phenomenon of people on the move is one of the most pressing issues of our time, assuming the proportions of a world "crisis". As Baker (2020) notes, terms like "refugees" and "migrants" have been coupled up with all sorts of appellatives such as "swarm", "tidal wave", "flood", even "infestation"-terms that evoke and provoke fear, dread, even revulsion. Baker however draws on Kansteiner (2018, p. 141) to help us put things in perspective, reminding us that during the so-called "refugee crisis" between 2015 and 2016, only 1.7\% of the 130 million forcibly displaced persons moved to the European Union, i.e., around 2.2 million people (half of whom were absorbed by just one country, Germany). Drawing on various sources for 2020 and 2021 data, the United Nations Refugee Agency (UNHCR) moreover notes that of the 82.4 million people worldwide forcibly displaced, 48 million actually remained within their country's borders (i.e., they are 'internally displaced'). Of those who try to find refuge outside their country, $86 \%$ are hosted in developing countries, while only $14 \%$ make it to developed countries (UNHCR, 2021). 
This article takes such numbers and percentages seriously, while remaining alert to the dangers of 'the spectacle of statistics in the production of crisis' that Stierhl et al. (2019) refer to. Mention of 'millions' has the extraordinary and ironic tendency to minimize and render invisible and faceless the pain in personal tragedies ... and, as we shall note, counsellors are not immune to such a process, even if their very identity has concern for the pain of others at its core. Kansteiner gives us additional numbers to think about, reminding those of us who live in the EU that a little more than 500 million European inhabitants had, in 2016, accumulated a combined GDP of a little less than $€ 14$ trillion-or $21 \%$ of global GDP. He caustically remarks that welcoming and hosting two million refugees 'hardly constitutes a serious financial or material challenge' (2018, p. 141). In contrast, Africa hosts $26 \%$ of the world's refugees, with Uganda, Kenya and Ethiopia leading the continent with more than 2.8 million refugees. That, notes Betts (2021), is seven times more than the United States, despite having an average GDP per capita sixty times lower.

\section{Positionality}

Without wanting to denigrate or in any way diminish the scope of the challenge that people's mobility represents to polities and communities - a challenge that is bound to deepen due to the climate emergency - it is nevertheless important to keep such a background at the forefront of our reflections on the issues at hand, and how these impact on our efforts to help the newly arrived access decent work. The way we practice career guidance - that is, our understanding of our task, the emotions we invest in it, and consequently, the approaches and strategies we deploy-inevitably flow from our understanding of the situation, what we consider what "the problem" is, and what is causing "it". As Vehviläinen and Souto (2021) point out, counsellors will avoid discussing important aspects of the lives of the refugees they care for if they themselves feel confused, ambiguous and possibly even hostile.

The fact that we are inexorably emotionally entangled when considering the "strangers" in our midst requires us all to consider our own positionality: we all inevitably have a point of view, and the most dangerous points of view are those that we are not aware of, i.e., our unconscious biases. In my case, for instance, my encounters with the "Other" mostly happen in the context of my home country Malta, a small island in the middle of the Mediterranean, which, like nearby Lampedusa, is often an unintended transit point for migrants on their way to mainland Europe. I am surrounded by competing discourses which shape the way Maltese think and feel: some highlight the Christian tradition of charity and hospitality; others claim that refugees are welcome because they bring economic benefits (i.e., cheap labour, especially in sectors that are unattractive to locals); and yet others warn that they are a threat to the island's cultural and religious identity, or that they might have a 'displacement effect' on native workers by either replacing them or depressing wages, especially in the low skills sector.

Even though I am unlikely to be displaced or replaced, I am not immune to such discourses, and have to work with and sort out contradictory thoughts and feelings that arise within myself, as a university professor, as a volunteer with 
refugee-serving NGOs, and as a citizen. Unwanted reactions happen despite myself, and despite the contradictions common to my class, where we typically enjoy world music, ethnic food, and exotic travel. Negative feelings nevertheless come to the surface when I smell food and hear sounds in my building that I am not accustomed to, or when languages are spoken around me which make me feel a stranger in my own home, or when I go to schools where teachers are struggling to communicate with children from several ethnic and linguistic backgrounds. I write this paper, therefore, with the conviction that one can only exorcize such thoughts and feelings if one faces what one fears. Denial—or dread that we might be considered reactionaryonly hamper the difficult process of knowledge of self and others. As Miller (2016) notes in his thoughtful reflections on the political philosophy of immigration, the refugee challenge requires us to 'grapple with contentious and sometimes intractable issues', obliging us to 'understand better what our fundamental beliefs and values are-what matters most to us when hard choices can no longer be avoided' (p. 165).

\section{The words we speak}

People's mobility across geographical and national borders can be temporary or permanent, can be seen as a final terminus or as stepping stones to other destinations, and can be driven by a range of disparate if often closely linked factors. These include war, climate change, lack of suitable employment opportunities in one's home country, escaping discrimination (due to ethnic and/or religious affiliation and/or sexual orientation), reunion with family, study abroad, and exploration of new ways of life. The liberalization of global labour markets as well as the expansion of mass transport technology have also facilitated and intensified the movement of peoples worldwide, to the extent that, as COVID-19 has brutally reminded us, a virus in one part of the globe can quickly become a contagion.

The different reasons for leaving one's community in order to enter into another one-whether for a fixed period of time or for life-also account for the different terms we use, which often signal a position on a continuum between "legality" and "illegality". Among the formal terms most often used are "migrant" (prefixed by such adjectives as "economic", "humanitarian", "documented" or "undocumented"), "people with subsidiary status", "newly-arrived", "asylum seeker", "refugee" (whether "resettled" or not), "forcibly displaced persons" and "unaccompanied minors." Informal terms used in different countries include "sans papiers" (in France) and "extracomunitari" (in Italy)_both of which highlight that those who are being referred to are considered (by some) to be on the fringes of, if not outside, legality. All these terms - and the confusions that they give rise to-signal the attempts by the modern state to control, manage, limit, and at times encourage the global flow of peoples, as well as to shape perceptions of the phenomenon. Attention to the language we use is therefore imperative. 


\section{Discursive ecologies}

More recently, we owe to the French philosopher Michel Foucault the important insight that there are dominant 'regimes of truth' that create 'discursive ecologies' in and through which power is exercised, and some things can be said (and therefore thought) and others cannot. As I have argued (Sultana, 2021), it makes a big difference to how we represent a problem (and therefore the action to take) if we speak of the "vulnerabilized" instead of the "vulnerable." Baker (2020), taking the lead from Foucault, reminds us that even dominant discourses can be contested and resisted, but that to be able to move outside the discursive cage that one swims in, like a fish in water, one needs to have a historical imagination. This can be fostered by engaging with a genealogical reading of concepts, which wakes us up to the fact that there are other ways of thinking of phenomena around us. Baker (2020, p. 12) examines some classical texts from ancient Greece 'as a source of inspiration, to help us envision an alternative language with which to speak about a key topic in contemporary life'. She shows that "refugees" were often referred to as "exiles", that these constituted a force to be taken seriously, and that those outside the polity were often extended a helping hand-if only out of self-interest, in case tables were turned and the host became the one seeking refuge. Protecting exiles was understood as an ethical imperative, to the extent that 'the exiles themselves [...] had enough agency to invoke that imperative and to shame those who saw fit to disregard it' (ibid., p. 14). One of the tests of incipient democracy, despite its well-known limitations (based as it was on slave labour and on the subordinate position of women), was a belief in human dignity, and on how the polis treated those seeking shelter.

\section{Bare life vs dignity and rights}

Words, therefore, are real in their consequences. A refugee's status as defined by national and international law has extensive implications for his or her ability to access rights-including opportunities in the labour market in the host country. The question however arises: what makes a person "legal" or "illegal"? Here too one can appeal to a number of discourses that shift us outside the frame of what is "allowed" to be thought. Some religious discourses emphasise that we are all 'children of God', and that each deserves respect, regardless. That kind of attitude was nicely caught by Pope Francis I in his Lenten message in 2015, when he denounced the 'globalisation of indifference', contrasting it with the need to 'globalise love' (Tan, 2019). In Islam, the notion of 'hijrah' grants "individuals the right to seek and to be granted asylum in any Muslim state [and] it is the duty of Muslims to accept and protect refugees for as long as they seek protection" (UNHCR, 2012, p. 1) Furthermore, if 'hijrah' is implemented, and in marked contrast to international refugee law, it is individuals and not states that determine the right to asylum.

Others reach the same or similar conclusions in a more secular manner, finding their inspiration in radical humanism. Both religious and secular discourses (which need not be seen in a binary opposition to each other) place the dignity and rights of individuals and groups above any classificatory system that allocates persons to 
a hierarchy, with some enjoying entitlements that others are denied. In this view, therefore, there is no person that deserves to be an 'homo sacer'-accursed, banned, and reviled by a community that 'others' him or her, and reducing him or her to what Agamben (1998) calls 'bare life'. A radical humanist would agree with many social justice activists that there are no "illegal migrants." There are only "illegal states", inasmuch as national boundaries and frontiers are historically contingent, and often the outcome of wars and of colonial intrigue.

Hegemonic views regarding migration are however so powerful that words fail and betray us, and we struggle to find a vocabulary that does not entrap us within the worldview that we know we must contest. Short of inventing a new language, which would render us incomprehensible to most, the options that remain tend to be awkward and clunky: putting every other word in scare quotes ends up being pedantic, while using interminable phrases (such as "persons with a history of migration" to remind us that there is a person behind the migrant) become impracticable. Throughout this article I will therefore use the term "migrants", "refugees" and "newly-arrived" interchangeably, while using other terms when I wish to emphasise issues specific to particular dislocatory experiences. In doing so, however, I hope to remain vigilant to the power of terminology in shaping thought, and to the slippery manner in which, according to Lacan, 'the world of words creates the world of things' (2001, p. 49).

With that in mind, we now turn to a somewhat more technical engagement (in the sense of considering "know what" and "know how") with the kinds of issues and insights that might be helpful to employment advisers as they strive to find effective and socially just ways of helping the newly arrived access livelihood. Techne, however, cannot and should not be divorced from values, nor science from conscience: As I hope I have shown above, career guidance is first and foremost a moral enterprise-i.e., concerned with "knowing how to be" and "knowing how to be with others." The skills we deploy have, as a goal, the fulfilment of that enterprise.

\section{The labour market integration of migrants and refugees}

When considering the experience of people on the move, the issue of integration in the host country's labour market is of primary importance. It is paid employment (or self-employment) that provides the migrant with access to a livelihood, which in itself supports other processes that facilitate inclusion in the community (Fedrigo et al., 2021). These include learning the local language/s, deeper understanding of local culture/s, and having access to facilities that enable independent living, such as the possibility of opening a bank account, paying rent, and accessing such services as health, education and training - all of which are likely to enhance constructive interactions with locals. In the global North, economic independence and self-sufficiency are generally considered positively by most communities, and are more likely to keep prejudice and rejection at bay. For all sorts of reasons, therefore, helping the newly arrived to find work is a most worthwhile task. 


\section{Complex challenges requiring integrated solutions}

Despite its positive impact on integration, however, paid employment in the formal labour market is especially difficult to secure for a good number of migrants. Typically, the latter have to face obstacles that include [a] lack of mastery of host country language/s-which includes inability to use the "right" accent, a "deficit" which often evokes stereotypes and prejudice (Chen, 2008, p. 424); [b] culture shock, which Chen (ibid., p. 425), citing various sources, defines as "anxiety arousal derived from contact with a new culture combined with feelings of confusion, loss and powerlessness"; [c] lack of recognised qualifications in skills, and [d] lack of social capital, knowledge and networks that facilitate access to employment (Chung et al., 2011, p. 94).

Career guidance, when conceived as part of a comprehensive package of linked services, can play a significant role in overcoming some of these obstacles. This is not surprising, and indeed recalls the origins of the field: one of the pioneers-Frank Parsons-is actually thought to have been motivated to develop career guidance in response to the migrants flocking to Boston. His adherence to the principles of mutuality and solidarity took root through actions that facilitated the absorption of newly arrived into the labour market (Hartung \& Blustein, 2002; Zytowski, 2001).

The inter-related nature of services in responding to the needs of the newly arrived is worth stressing further. While work has such a fundamental importance in a migrant's life, it should nevertheless be noted that his or her career development experience and vocational life 'always coexists with other aspects of these individuals' personal and social lives' (Chen, 2008, p. 422). Language training, for instance, is linked to employment, work experience, internships, and/or apprenticeships (Konle-Seidl \& Bolits, 2016, pp. 35, 37). Indeed, as we will see below, most of the career guidance approaches that are used with migrants acknowledge that access to work facilitates other transitions that a newly arrived has to make, and that therefore one cannot think of interrelated issues independently of each other, as if they were in silos. Career guidance services will therefore have to be conceived in the broadest terms possible, where issues to do with self-identity, cultural competence, awareness of one's duties and rights, and so on are all relevant.

This close relationship between different aspects of the act of moving to, and integrating in, a host country is quite evident when we consider the issue of selfidentity - what Magnano et al. (2021) refer to as a 'sense of self in transition'. This 'sense of self' is further foregrounded due to the confusion and multiple challenges migrants tend to experience as they try to decode their new surroundings. As Chen (2008, p. 432) notes, the loss of migrants' vocational or career identity in the host country 'often severely lessens or diminishes immigrant workers' positive sense in their selfhood.' This leads to 'a weakened and more negative self-concept.' Chen argues that 'a crippled vocational self-concept can have a devastating impact on immigrants' total self-concept system, which in turn, can come back to affect their effort to re-establish their career self-identity in the new environment'. In this regard, Federigo and his colleagues (2021) draw 
on capability theory to highlight the way in which migrants develop a sense of 'possible selves', where 'adaptive preferences' come into play in response to perceived choices within constraints, and in the search not just of livelihood, but also of development of potential and of flourishing.

\section{Diverse transitions and trajectories: shared and specific concerns}

The range of terms used to categorise migrants and refugees that were referred to earlier serve to signal not only legal status, but also to remind us that the relocation experience can be quite different between one group and another. Despite such significant differences, international comparative research suggests that there are many overlapping and shared concerns (Yakushko et al., 2008). The most influential factors in career development process of migrants are likely to be similar, namely limited knowledge about a range of factors that have already been noted-i.e., about language, possible work options, strategies for finding and keeping a job, work-related cultural norms and expectations, and rights one is entitled to, especially if confronted by racism, prejudice, and discrimination.

Some of this international research actually notes the emergence of a 'standard package' and 'conventional wisdom' in the field of labour market integration of migrants. Martín et al., (2016, p. 9; see also Zacher, 2019) identify four key elements of this package, which flow from our understanding of the challenges that the newly arrived have to face. Such 'standard packages' typically include the following services:

[a] early skills assessment;

[b] introduction programmes including general cultural orientation, socio-professional orientation, training and apprenticeships;

[c] intensive language courses; and

[d] access to general job intermediation services.

Career guidance is often an embedded element in this package, though sometimes it is offered as a distinct and recognisable service that could include clarification of goals, accreditation of prior learning and experience, work shadowing, and learning how to increase one's employability—such as through self-presentation skills, cv writing, and sitting for interviews.

A central aspect of this 'package' is the drawing up of individualized integration plans where language, civic and working life skills, vocational education and training, subsidised job placements, and rehabilitation help improve the match between immigrants' pre-existing skills and training and employment offered. The process of working with trained career counsellors in co-constructing an understanding of the situation, in considering options, in building on strengths, and in mobilising institutional resources and social capital can go a long way in attenuating feelings of rejection, confusion, frustration and powerlessness, and in staving off low self-efficacy and low outcome expectations, which, according to Yakushko et al. (2008) can be one of the biggest barriers to career development. 
When done well, action planning can bolster the agentic capacity of individuals and groups, who may have been overcome by feelings of resignation and paralysis in front of cumulative effect of not just vocational, but also personal and social challenges that resettlement represents (Chen, 2008; Petersen et al., 2021).

While such 'standard packages' are valuable, they should not replace tailor-made programmes that attempt to respond to the specific situation of different groups of newly arrived, whose needs are not served by the raft of services provided to other migrants. Humanitarian refugees and survival migrants, for instance, are likely to have suffered extensive trauma and psychological distress, which requires services that are targeted, coordinated, and comprehensive. Highly qualified migrants, on their part, face different sets of challenges (Ennerberg, 2021; Knappert et al., 2019), as will note further on. Women, LGBTI people, and persons with disability can be exposed to even more trenchant discrimination, with their rights and needs being deemed secondary to their male, able-bodied or heterosexual counterparts. One therefore needs to remain sensitive to 'differences in how people are treated, the rights they are granted, the forms of discrimination they face, and the freedoms that are open to them' (Andrijasevic et al., 2019, p. 1).

\section{Research, policy and practice: views and reviews}

Different elements of the 'standard package' noted above are likely to be helpful, especially when a comprehensive and linked approach is adopted. However, career practitioners informed by a social justice approach should also keep in mind that it is not only the "supply" side that needs attention: so too does the "demand" side. In other ways, there are systemic ways of improving the chances of migrants to find regular and meaningful work. Some of these ways are more acceptable than others: the Danish government's subsidies to private employers to make the employment of foreigners more attractive is certainly more progressive than the flexibilization of the labour market through, for instance, reducing the minimum wage, or making it easier for employers to hire and fire, often to the detriment not just of the newly arrived, but to the local precariat, whose hostility to migrants and refugees is further fanned by such "incentives".

The main point being made here is that the onus for labour market integration of the newly arrived should not fall solely on the latter's shoulders: the state can develop policies that facilitate such integration, whether at the macro-level, as noted above, or at the meso- and micro-levels. Among others, such policies could include low caseloads for time-intensive counselling for job-ready immigrants and refugees at risk of long-term unemployment (as in Sweden), or the establishment of a free legal service for migrants who feel they are being exploited or discriminated against (as in Malta). Civil society too has an important part to play (Frigerio \& Nasimi, 2019; Thomsen, 2012; Vehviläinen \& Souto, 2021). In Denmark, Sweden and the UK, for instance, volunteer mentors serve as 'introduction guides', helping migrants access employment-related networks, providing insider knowledge to bridge cultural gaps, and directing individuals towards the most appropriate support and training 
programmes. Some adopt a more explicit advocacy role by, for instance, raising awareness among employers and trade unions of benefits of employing refugees. The effectiveness of such mentors is likely to be more pronounced when, as in the case of the 'link officer' in the UK, they themselves are former refugees.

Another policy-driven service that can also facilitate the labour market integration of the newly arrived is the accreditation of prior learning. Many refugees and asylum-seekers escaping conflict or persecution are unable to carry their certificates with them, and cannot therefore prove the extensive education and training they received in their home country. Even when they do have such evidence, it is not uncommon to face difficulties in having their qualifications recognised, or in establishing fair equivalence with those in the country they have moved to. This leads to "role shocks" and threats to "career identity", often the outcome of "occupational closure" by professions-such as medical doctors, engineers, accountants, and teachers-obliging highly qualified immigrants to settle for jobs at a lower level than in their home country (Ennerberg, 2021).

There are now several programmes in place which address issues such as these, with national qualifications frameworks rendering the establishment of equivalence more feasible. Recognition and accreditation strategies can be nation-based, as with the Norwegian scheme, which uses a combination of academic assessments, home assignments, and a mapping of work history in order to match migrants to the demand for specific skills. They can also be spearheaded by regional and international organisations, such as in the case of the UNESCO Qualifications Passport for Refugees and Vulnerable Migrants, and the Council of Europe's European Qualifications for Refugees (Council of Europe, 2020).

An important aspect of such service provision to the newly arrived is timeliness. As has already been noted, employment is critical since it has important multiplier effects in several aspects of an individual's life in the host country. Not only does waged employment in the formal labour market facilitate the process of psychosocial adjustment, but it also enhances the likelihood of integration by helping individuals (and their dependents) to put down roots, to build up social and supportive networks, and to develop linguistic and cultural competences (Chung et al., 2011, p. 93). However, these material and psychosocial benefits are more likely to be enjoyed the faster integration in labour market is achieved, and each month spent in unemployment makes it all the more difficult to find a job (Konle-Seidl \& Bolits, 2016). Furthermore, the more quickly migrants become economically independent, the more likely it is that prejudice against them is kept at bay, since they will be paying their tax and social security contributions and thus less likely to be perceived as a burden. On their part, migrants in decent employment are less likely to experience frustration, and more likely to feel positive about their new home.

Prompt career counselling is more apt to take into account - and facilitate - the different phases involved in making a career transition, such as immobilization, shock, minimization of change, self-doubt, letting go of negative appraisals, testing new options, search for meaning, and integration and renewal' (Yakushko et al., 2008, p. 380). An awareness of the different phases of transition can, in principle, lead to appropriate support being offered at each phase. Similarly, awareness of the 
multiple transitions involved across these different phases-whether in terms of employment, housing, community involvement, and so on-should also impact the design of appropriately supportive, holistic and integrated services (Abkhezer et al., 2021).

Career guidance has not remained passive in front of the challenges posed by people on the move, but has attempted to respond in meaningful ways by:

- mobilising theoretical frameworks that are fit for purpose;

- developing and enhancing training programmes for practitioners;

- drawing on the lessons learnt by those in the field.

Each of these will be briefly considered in turn.

\section{Facing the challenge}

\section{Mobilising theoretical frameworks that are fit for purpose}

Academics from the career guidance field have made significant efforts to understand and respond to the situations generated by migration. This 'sense-making' and critical reflection have been the subject of several special thematic issues of national, regional and international journals dedicated to career guidance, including, among others, Zalaquett (2011), Newman et al. (2018), Andrijasevic et al. (2019), Hughes et al., (2019a, 2019b), Richardson et al. (2019a, b), Olry-Louis (2020) and Fejes et al. (2021).

The career guidance field has developed important funds of knowledge over the years, generating insights that help practitioners make sense of and respond to situations that are marked by complexity. Awareness of such complexity has given rise to more sophisticated theoretical frameworks that acknowledge the multi-level interaction between individuals, groups, and social contexts in an effort to promote life-career development. Such approaches stress that social and economic contexts matter, and that it is not possible to promote career human agency of diverse populations without taking into account the dynamic interplay between cultural, contextual, and psychosocial factors in the life design process (Chen, 2008, p. 436; Dunwoodie et al., 2021).

Foremost among such frameworks is Social Cognitive Career Theory (Brown \& Lent, 2017; Lent \& Brown, 2019) which highlights the role of self-efficacy and outcome expectations, while acknowledging the impact not only of personal factors (such as gender, ethnicity) but also the contextual factors (such as sexist, racist and xenophobic attitudes), which restrict most openings to low-paid, dead-end jobs (Yakushko et al., 2008), or worse still, to seasonal work (Konle-Seidl \& Bolits, 2016). Similarly, the Career Eco-System Model recognises that individuals and institutions 'operate in a mutually interdependent and recursive fashion thus capturing both the structural and agentic nature of careers' (Richardson et al., 2019a, p. 2). It thus draws attention to the impact of public policy 'signalling how inefficient and cumbersome employment policies can deter employers from providing 
opportunities for refugees' (Richardson et al., 2019a, p. 9). Constructivist (and storied) approaches (Pierce \& Gibbons, 2012), on their part, are especially effective when informed by critical awareness of patterns of systemic injustice (Abkhezr et al., 2018, 2021; Magnano et al., 2021; Reid, 2017), and can be particularly powerful and fitting when working with refugees, deploying as they do narrative counselling techniques that acknowledge the concept of multiple realities. They thus enhance the possibility of understanding the 'Other' through the use of life space mapping activities, and by drawing on a range of disciplines (including philosophy, psychology, sociology, and cultural studies) in order to ensure a holistic engagement with clients.

Other related theoretical approaches include Contextualist Career Theory, which postulates that 'contextual meaning making holds the key to individuals' intentional actions in their life and career projects' (Chen, 2008, p. 436); Systems Theory (see Abkhezr et al., 2021; Magnano et al., 2021), Hope Action theory (Hughes et al, 2019b); the Cultural Preparedness model (Arulmani, 2019), the Cross-Cultural Life-Career Development (CCLCD) Framework (Chen, 2008); and Integrative Life Planning (Hansen, 2011). These diverse approaches 'all acknowledge the importance of cultural sensitivity, of the need for holistic and multidisciplinary engagement with the newly arrived, and of the need to think of transition to work as part of a broader spectrum of life planning' (Chen, 2008, p. 433).

Some of these approaches also attempt to explicitly integrate advocacy and policy work in their efforts to support the newly arrived. Blustein et al.'s (2005) Emancipatory Communitarian Approach, for instance, makes it a point to take social and economic forces into account, and not just internal psychological states and resources, when trying to understand the positions that people occupy inside, at the edge of, and outside the labour market. Advocacy here becomes part and parcel of the design of services purporting to support vulnerable and vulnerabilized groups, acknowledging the many contextual barriers that constrain career development in and through work, while highlighting the resources that individuals and groups bring to the complex and multi-faceted transitions they need to affect. This, of course, is vital, since it is precisely at the interstices of structure and agency that advocacy and emancipatory action can make the difference between potential and flourishing (Vehviläinen \& Souto, 2021).

The focus on agency is important, of course, not least because, as Fedrigo and his colleagues (2021) point out, it is crucial to avoid thinking of immigrants in terms of their deficits rather than in terms of the resources they have and what they can contribute to the host country. At the same time, and as noted earlier in relation to some versions of integrative action planning, one has to be wary of agentic approaches that emphasise individual resilience, positive psychology, and voluntaristic life design as these can easily lead to responsibilisation of individuals rather than of social structures (Hooley et al., 2018, 2019). Agentic approaches informed by a commitment to social justice can, however, serve to strengthen the advocacy element in career guidance with immigrants, thus promoting a critical humanist imperative committed to the principle that all lives matter. As Magnano et al. (2021) put it, one has to take into account both 'restrictive voices' and 'agentic voices' if one is to attend to the career development needs of migrants and refugees. 


\section{Enhanced training programmes}

National and regional studies among career guidance practitioners suggest that many feel insufficiently prepared to offer adequate services to newly arrived and to cater for culturally diverse groups (see, inter alia, Launikari \& Puukari, 2005; Sultana \& Watts, 2006; CEDEFOP, 2009; Reid, 2017; Sultana, 2017). An increasing number of career guidance pre-service and in-service training programmes now include cultural awareness and sensitivity to diversity as a core component (CEDEFOP, 2009), with some projects attempting to set out the curricular areas that need to be developed to cater for the labour market integration and career development of refugees (Kohn, 2019, p. 15). Competence frameworks (such as those put together by the International Association for Educational and Vocational Guidance or the Network for Innovation in Career Guidance and Counselling in Europe) and national professional standards (such as those of the Career Industry Council of Australia) highlight the skills needed by practitioners to facilitate the inclusion of individuals and groups with a diverse background into the labour market.

There have also been several regional and international projects which set out to identify the various skills, competences, values, attitudes and dispositions that are needed to cater for migrants and refugees. In the case of such a project for instance, Kohn (2019) —one of the coordinators of an Academia +EU-funded project going by the name of "Counsellors' Study and Training Exchange Programme"- -strongly recommends that requisite competences should be offered at a post-graduate level given the multi-disciplinary knowledge base that practitioners need to master. Another example is provided by Atay et al. (2019), whose 'CminaR' programme developed training resources to help employment advisors better appreciate the complex issues that migration throws up. These resources help career workers understand that some of the language and terms used in career guidance need to be problematised, that they should beware blaming the victim for system-caused injustices, and that they need to be sensitive to the fact that requiring migrants and refugees to speak about their journey to the host country might cause them to relive the trauma. Practical advice is offered in finding ways to help the recently arrived, such as, for instance, by reframing their experience with obstacles as an indication of their strength, courage, and tenacity.

These projects and publications acknowledge the point made at the start of this article, namely that training programmes with career practitioners need to put a special emphasis on helping individuals become aware of their own biases, the stereotypes they hold (consciously or unconsciously), and the reconceptualising of their work in terms of advocacy for groups rendered vulnerable due to their migrant status. Most indeed argue that training programmes need to start off with a module dedicated to the unlearning of a number of assumptions in order to be able to work as a career advisor with refugees (inter alia, Kohn, 2017; Sultana, 2017).

Many practitioners recognise the need for attitudinal change and for overcoming of prejudice that are often deeply embedded in all of us due to the nefarious influence of reactionary views that have become increasingly normalised, and which are promoted by mainstream media. Such views reproduce negative myths, stereotypes, and perceptions about migrants and refugees-e.g., that they are a strain 
on the economy; that they deplete resources; that they take jobs from native-born; that they exploit social welfare systems; and that they are a vector for illnesses and for crime-views that are exacerbated during periods of economic downturns, and with some stereotypes being produced and reproduced even among diverse migrant groups.

Training can help avoid 'political countertransference', i.e., the unconscious internalization of negative messages which lead some counsellors to give in to intolerance and outright xenophobia (Chung et al., 2011, p. 89). Resistance to such widely held prejudice requires practitioners to engage with an education that is a process of unlearning - by reading, for instance, ground-breaking texts, such as the one by Hansen (2021), whose rigorous analysis of the economic benefits of migrants and refugees in Sweden puts paid to increasingly popular but misguided restrictive asylum policies, where the newly arrived are seen as a fiscal burder to the state and polity, and where interests and rights are necessarily at odds and cannot be aligned. In other words, there are solid, well-researched arguments, as well as robust evidence, that give the additional 'comfort' of self-interest to complement rather than to challenge the ethical imperative to welcome the stranger, no matter what. Career counsellors who develop a deeper, more informed and critical understanding of their calling are more likely to commit to advocacy at the place of work. They are also more likely to be active citizens in the public sphere, by highlighting the cultural, economic and civic contributions that migrants and refugees make to the host society, contesting the dominant discourse that they are, perforce, a burden.

Another aspect of the knowledge base that is required by career guidance practitioners working with the newly arrived refers to the need for multicultural counsellors to be aware of pre-migration and post-migration challenges that have an impact on psychosocial adjustment to a new culture (Chung et al., 2011, p. 95). Such a knowledge base would include understanding of a range of issues, including 'reasons for migration, political and economic context of the home country, language barriers, loss and grief, changes in identity, dealing with xenophobia, discrimination, stereotypes, family relations and intergenerational conflicts, acculturation, cultural shock, survivor's guilt, mental and physical health problems' and so on (Bemak \& Chung, 2008).

This again suggests that professionals might be required to take on expanded roles that they may not have been trained for in their initial training, including consultant, advisor, teacher, therapist, facilitator, advocate, change agent, and case manager, besides also being open to learning from their clients and the clients' community in order to better understand their world views and cultural practices (Petersen et al., 2021; Chung et al., 2011). It is difficult to imagine employment advisors having a command of such a wide range of skills, and this in fact signals the importance for career advisor training to include competences in working in interdisciplinary teams. 


\section{Learning from each other}

There remain, of course, important knowledge gaps when it comes to effective mobilisation of career guidance in support of the newly arrived (CEDEFOP, 2009; Hughes et al., 2019a; Konle-Seidl \& Bolits, 2016; Martín et al., 2016). Longitudinal studies that shed light on what happens to migrants and refugees after finding employment is especially crucial if we are to understand their experience-including that of their children-in a more comprehensive manner (Hughes et al., 2019b, p. 5). Despite limitations such as these, there is still much that we can learn from each other's efforts, and from the increasing number of case studies that describe the efforts of practitioners to respond to the situations they face in the field.

Konle-Seidl and Bolits (2016), for instance, have put together a valuable compendium of practical initiatives, be they volunteer networks that assist resettled refugees upon arrival, or the setting up of one-stop shops to facilitate linked and holistic service provision (as in Slovenia and Portugal). Such case studies also serve to highlight the ingenuity, creativity and political commitment of those catering for needs that were not envisaged when institutional structures and practices were first put into place.

Especially promising are initiatives that are built from the ground up, and which draw on the knowledge base available such that researchers, policy entrepreneurs, and practitioners work hand in hand towards the same goal. A case in point is the CLEAR model reported by Oguzertem (2019), which brings together many of the elements highlighted in this paper by promoting certainty of status, language training, $\underline{e}$ ducation opportunities, $\underline{a}$ id as an investment, and $\underline{r}$ ight to work as key components contributing to the reintegration and resettlement process.

There is of course no recipe that is universally applicable. In some contexts, for instance, one could argue that refugee interests and integration are better served when specialised support is phased out as quickly as possible and replaced by access to mainstream support available to other residents. This might have the salutary effect of making the newly arrived stick out less as "exceptions", with a different status to locals. Nevertheless, the emerging consensus around what is likely to be helpful to migrants and refugees can be a useful foundation for the development and adoption of programmes informed by a commitment to social justice. Such MultiLevel Models are not just based on the usual range of so-called employability skills, but also work with the newly arrived in naming and contesting the different faces of oppression and discrimination.

\section{Conclusion}

In this paper I set out to, first of all, problematise some of the representations, debates and arguments around migrants and refugees. I did this by showing how the very vocabulary we use predisposes us to think of the phenomenon in terms of a crisis, and as a fiscal burden to the state. I argued that an objective consideration of facts, as well as a historical and critical imagination, help us see beyond the discursive ecology that we operate in, in order to be able to imagine alternative ways 
of thinking and of being. Such conscientisation, I stressed, is essential if counsellors are to provide a service that is emancipatory and informed by social justice.

The paper then provides a synthesis of some of the relevant literature on the labour market integration of the newly arrived. This leads to a consideration of the role that career guidance can play, especially when it is part of a connected set of integrated systems. Here, issues to do with self-identity, cultural competence, and awareness of one's duties and rights, among others, are all relevant. The paper argues that guidance has the potential of addressing both capability and possibility, especially when it eschews an emphasis on individual resilience, on positive psychology, and on voluntaristic life design that can easily lead to responsibilisation of individuals rather than of social structures.

The paper finally identifies a number of initiatives that suggest that career guidance is rising to the challenge of catering for a diverse group of migrants by mobilising theoretical frameworks that are fit for purpose, by developing and enhancing training programmes for practitioners, and by drawing on the lessons learnt by those in the field.

It is in ways such as these that the career guidance field can respond to the call made by the International Association for Educational and Vocational Guidance in its communiqué, which urges against a career agenda that is solely 'driven by economic rationalist arguments', and to embrace instead 'social justice as a core value that guides practices' (IAEVG, 2013, p. 2). This paper signs up to such principles, and endorses them wholeheartedly.

\section{References}

Abkhezr, P., McMahon, M., Glasheen, K., \& Campbell, M. (2018). Finding voice through narrative storytelling: An exploration of the career development of young African females with refugee backgrounds. Journal for Vocational Behavior, 105, 17-30.

Abkhezr, P., McMahon, M., Glasheen, K., \& Campbell, M. (2021). A systemic and qualitative exploration of career adaptability among young people with refugee backgrounds. International Journal for Educational and Vocational Guidance. https://doi.org/10.1007/s10775-020-09446-Z

Agamben, G. (1998). Homo Sacer. Sovereign power and bare life. Stanford University Press.

Andrijasevic, R., Rhodes, C., \& Yu, K-H. (Eds.). (2019). Special issue on "Foreign workers: On the other side of gendered, racial, political and ethical borders". Organization. https://doi.org/10.1177/13505 08419828583

Arulmani, G. (2019). The cultural preparedness model of aspiration and engagement: Understanding the dynamics of integration. British Journal of Guidance \& Counselling, 47(1), 20-34.

Atay, S., Chant, A., Conrads, R., Engelen-Kefer, U., Ferrari, L., Gülmez, N., Hertzberg, F., Hirasawa, K., Kohn, K.-H. P., Ghaffari, D. M., Nix, C., Nota, L., Reid, H., Sgaramella, T. M., Sundelin, Å., Weber, P. C. (2019). Counselling refugees means modernising counselling. https://www.cminar.eu/ upload/files/Book_CMinaR_project-outputs-and-evaluation\%281\%29.pdf

Baker, M. (2020). Rehumanizing the migrant: The translated past as a resource for refashioning the contemporary discourse of the (radical) left. Palgrave Communications, 6(1), 1-15.

Bemak, F. \& Chung, R. C-Y. (2008). Counseling refuges and migrants. In P. B. Pedersen, J. G. Draguns, W. J. Lonner, \& J. E. Trimble (Eds.), Counseling Across Cultures (6th ed., pp. 307-324). Sage.

Betts, A. (2021). The United States can afford more refugees. Boston Review, June. http://bostonreview. net/global-justice/alexander-betts-what-biden-can-learn-africas-refugee-policy

Blustein, D. L., McWhirter, E. H., \& Perry, J. C. (2005). An Emancipatory Communitarian Approach to vocational development theory, research, and practice. The Counseling Psychologist, 33(2), $141-179$. 
Brown, S. D., \& Lent, R. W. (2017). Social cognitive career theory in a diverse world. Journal of Career Assessment, 25(1), 173-180.

CEDEFOP. (2009). Professionalising career guidance: Practitioner competences and qualification routes in Europe. CEDEFOP Panorama Series 164. Office for Official Publications of the European Communities.

Chen, C. P. (2008). Career guidance with immigrants. In J. A. Athanasou \& R. Van Esbroeck (Eds.), International handbook of career Guidance (pp. 419-437). Springer.

Chung, R.C.-Y., Bemak, F., \& Grabosky, T. K. (2011). Multicultural-social justice leadership strategies: Counseling and advocacy with immigrants. Journal for Social Action in Counseling and Psychology, 3(1), 86-102.

Council of Europe. (2020). European Qualifications Passport for Refugees. https://rm.coe.int/eqpr-leafl et-en-web-july-2020/16809ee917

Dunwoodie, K., Due, C., Baker, S., Newman, A., \& Tran, C. (2021). Supporting (or not) the career development of culturally and linguistically diverse migrants and refugees in universities: Insights from Australia. International Journal for Educational and Vocational Guidance. https://doi.org/10.1007/ s10775-021-09506-y

Ennerberg, E. (2021). Fast track to the labour market? Experiences of learning in an active labour market policy measure for migrant teachers in Sweden. International Journal for Educational and Vocational Guidance. https://doi.org/10.1007/s10775-021-09461-8

Fedrigo, L., Udayar, S., Toscanelli, C., Clot-Siegrist, E., Durante, F., \& Masdonati, J. (2021). Young refugees' and asylum seekers' career choices: A qualitative investigation. International Journal for Educational and Vocational Guidance. https://doi.org/10.1007/s10775-021-09460-9.

Fejes, A., Chamberland, M., \& Sultana, R. G. (2021). Special issue on migration, educational and career guidance, and social inclusion. International Journal for Educational and Vocational Guidance. https://doi.org/10.1007/s10775-021-09493-0

Frigerio, G., \& Nasimi, R. (2019). Who is supporting the career development of refugees? The role of grassroots organisations. NICEC Journal, 42, 40-46.

Hansen, P. (2021). A modern migration theory: An alternative approach to failed EU policy. Agenda.

Hansen, S. S. (2011). Integrative life planning: A holistic approach. Journal of Employment Counseling, 48(4), 167-169.

Hartung, P. J., \& Blustein, D. L. (2002). Reason, intuition, and social justice: Elaborating on Parsons's career decision-making model. Journal of Counseling and Development, 80(1), 41-47.

Hooley, T., Sultana, R. G., \& Thomsen, R. (Eds.). (2018). Career guidance for social justice: Contesting neoliberalism. Routledge.

Hooley, T., Sultana, R. G., \& Thomsen, R. (Eds.). (2019). Career guidance for emancipation: Reclaiming justice for the multitude. Routledge.

Hughes, D., Akkök, F., Arulmani, G., \& Zelloth, H. (Eds.). (2019a). Special issue on "Migration: Theory, research and practice in guidance and counselling". British Journal of Guidance \& Counselling. https://doi.org/10.1080/03069885.2018.1564898

Hughes, D., Akkök, F., Arulmani, G., \& Zelloth, H. (2019b). Migration: Theory, research and practice in guidance and counselling. British Journal of Guidance \& Counselling, 47(1), 1-5.

IAEVG (2013). Communiqué on social justice. https://iaevg.com.

Kansteiner, W. (2018). Unsettling crime: Memory, migration, and prime time fiction. In M. BachmannMedick \& J. Kugele (Eds.), Migration: Changing concepts, critical approaches (pp. 141-166). De Gruyter.

Knappert, L., van Dijk, H., \& Ross, V. (2019). Refugees' inclusion at work: A qualitative cross-level analysis. Career Development International, 25(1), 32-48.

Kohn, K.-H. P. (2017). Specific career counselling for refugees-the key to tapping a significant potential of skilled workers. In C. Kreklau \& J. Siegers (Eds.), Handbuch der Aus- und Weiterbildung. Politik, Praxis, Finanzielle Förderung [Handbook of vocational and further training. politics, practice, financial support]. Loseblattwerke Deutscher Wirtschaftsdienst.

Kohn, K.-H. P. (2019). Requirements and Preferences of lecturers, students and career counsellors dealing with building up competences needed in settings of counselling for refugee and migrant integration into the labour market: Transnational synthesis of the Outcome of national Delphi-Reports. CMINAR: Teaching Career Counsellors of Refugees (Intellectual Output 2).

Konle-Seidl, R., \& Bolits, G. (2016). Labour market integration of refugees: Strategies and good practices. Policy Department A-Economic and Scientific Policy/DG Internal Policies. IP/A/ EMPL/2016-08; PE 578.956. 
Lacan, J. (2001). Écrits: A selection. Routledge [original edition, 1966, Éditions du Seuil].

Launikari, M., \& Puukari, S. (Eds.) (2005). Multicultural guidance and counselling-Theoretical foundations and best practices in Europe. Centre for International Mobility CIMO \& Institute for Educational Research.

Lent, R. W., \& Brown, S. D. (2019). Social cognitive career theory at 25: Empirical status of the interest, choice, and performance models. Journal of Vocational Behavior, 115, 103316.

Magnano, P., Zarbo, R., Zammitti, A., \& Sgaramella, T. M. (2021). Approaches and strategies for understanding the career development needs of migrants and refugees: The potential of a systems-based narrative approach. International Journal for Educational and Vocational Guidance. https://doi.org/ 10.1007/s10775-020-09457-w

Martín, I., Arcarons, A., Aumüller, J., Bevelander, P., Emilsson, \& Henrik, K. S. (2016). From Refugees to workers mapping labour-market integration support measures for asylum seekers and refugees in EU member states, Vol. I: Comparative Analysis and Policy Findings. Migration Policy Centre (MPC) at the Robert Schuman Centre for Advanced Studies of the European University Institute in Florence (EUI), in collaboration with Bertelsmann Stiftung.

Miller, D. (2016). Strangers in our midst: The political philosophy of immigration. Harvard University Press.

Newman, A., Bimrose, J., Nielsen, I., \& Zacher, H. (2018). Special issue on "Vocational behavior of refugees: How do refugees seek employment, overcome work-related challenges, and navigate their careers?". Journal of Vocational Behavior, 105, 1-5.

Oguzertem, I. (2019). What are the barriers to integrating displaced populations into labor markets and what are possible steps to overcome them? Career Development International, 25(1), 19-23.

Olry-Louis, I. (2020). Special issue on "Migrations internationales et orientation" [International Migrations and career guidance]. L'orientation Scolaire Et Professionnelle, 49(3), 383-399.

Petersen, I.-L., Mariager-Anderson, K., Patillon, T. V., \& Bernaud, J.-L. (2021). Existential career guidance for groups of young refugees and migrants: A Danish initiative. International Journal for Educational and Vocational Guidance (Online First).

Pierce, L. M., \& Gibbons, M. M. (2012). An ever-changing meaning: A career constructivist application to working with African refugees. Journal of Humanistic Counseling, 51(1), 114-127.

Reid, H. (2017). What do practitioners need to know about the career guidance needs and experiences of asylum-seeking, refugee and migrant populations? Paper presented at the IAEVG Conference in Mexico, November.

Richardson, J., Karam, C. M, \& Afiouni, F. (Eds.) (2019a). Special issue on "The Impact of the global refugee crisis on the career ecosystem". Career Development International. https://doi.org/10.1108/ cdi-04-2019-0104

Richardson, J., Karam, C. M., \& Afiouni, F. (2019b). The global refugee crisis and the career ecosystem. Career Development International, 25(1), 1-13.

Stewart, J. R., \& Stringer, C. B. (2012). Human evolution out of Africa: The role of refugia and climate change. Science (american Association for the Advancement of Science), 335(6074), 1317-1321.

Stierhl, M., Heller, C., \& De Genova, N. (2019). Numbers (or, the spectacle of statistics in the production of "crisis"). New keywords collective: Europe/crisis: New key-words of "the crisis" in and of "Europe". http://nearfuturesonline.org/europecrisis-new-keywo rds-of-crisis-in-and-of-europe-part-4/.

Sultana, R. G. (2017). Career guidance in multicultural societies: Identity, alterity, epiphanies and pitfalls. British Journal of Guidance \& Counselling, 45(5), 451-462.

Sultana, R. G. (2021). Closing commentary, opening conversations: Liminal reflections on decent work, emerging adulthood, and social justice. Emerging Adulthood. https://doi.org/10.1177/2167696821 1029760

Sultana, R. G., \& Watts, A. G. (2006). Career guidance in public employment services across Europe. International Journal for Educational and Vocational Guidance, 6(1), 29-46.

Tan, J. Y. (2019). Pope Francis's preferential option for migrants, refugees, and asylum seekers. International Bulletin of Mission Research, 43(1), 58-66.

Thomsen, R. (2012). Career guidance in communities. Aarhus Universitetsforlag.

United Nations. (2013). Secretary-General's remarks to high-level dialogue on International Migration and Development. https://www.un.org/sg/en/content/sg/statement/2013-10-03/secretary-generalsremarks-high-level-dialogue-international.

United Nations Refugee Agency. (2012). Islam and refugees. https://www.unhcr.org/protection/hcdia logue\%20/50ab90399/islam-refugees.html 
United Nations Refugee Agency. (2021). Figures at a glance. https://www.unhcr.org/figures-at-a-glance.html Vehviläinen, S., \& Souto, A.-M. (2021). How does career guidance at schools encounter migrant young people? Interactional practices that hinder socially just guidance. International Journal for Educational and Vocational Guidance. https://doi.org/10.1007/s10775-021-09467-2

Yakushko, O., Backhaus, A., Watson, M., Ngaruiya, K., \& Gonzalez, J. (2008). Career development concerns of recent immigrants and refugees. Journal of Career Development, 34(4), 362-396.

Zacher, H. (2019). Career development of refugees. In A. Athanasiou \& H. N. Perera (Eds.), International handbook of career guidance (2nd ed., pp. 359-384). Springer.

Zalaquett, C. P. (Ed.). (2011). Special Issue on "Multicultural social justice leadership development". Journal for Social Action in Counseling and Psychology. https://doi.org/10.33043/JSACP.3.1

Zytowski, D. G. (2001). Frank parsons and the progressive movement. The Career Development Quarterly, 50(1), 57-65.

Publisher's Note Springer Nature remains neutral with regard to jurisdictional claims in published maps and institutional affiliations. 